\title{
WESTERN PAINTED TURTLE \\ HATCHLINGS OVERWINTERING \\ IN MANITOBA NESTS
}

W.H. KOONZ MB, Dept. Of Nat. Res.Box 24, 200 Saulteaux Cr. Winnipeg, MB R3J 3W3

Manitoba's two turtle species, the western painted turtle and the common snapping turtle, reach the northern limits of their ranges in southern Manitoba. Adults of both species normally winter on the bottoms of ponds and rivers ${ }^{2}$. The females of both species lay their eggs in holes (nests) in the ground which they excavate in late spring (June). The eggs, incubated by the sun, hatch in the fall. One adaptation to cold climates is the turtle's ability to produce extra-cellular antifreeze which allows them to survive below freezing temperatures ${ }^{3}$. Another adaptation, recognized in other northern parts of their range, is the ability of turtle hatchlings to remain in the nest over winter before making their way to water the following spring ${ }^{4}$. While this overwintering behaviour has been documented elsewhere in the turtle's range, it has not been recognized in Manitoba or on the Canadian prairies.

The fact that young turtles overwinter in the nest was made clear to me when Doug Collicutt and I collected western painted turtle eggs for Dr. Ken Storey, a cryogenics (freeze tolerance) researcher from Carlton University, Ottawa. In early July 1989, we dug up some 127 painted turtle eggs from nine roadside nests in Turtle Mountain Provincial Park near Boissevain, Manitoba. We carefully placed the eggs in layers of sand in a plastic pail and transported them to Winnipeg. We dug the pail into a full sun portion of Doug's driveway and covered the top with screen to prevent predation. On 10 October, 1989 we uncovered the pail to check on the hatchlings. Over 100 had hatched (Fig. 1). Each young turtle had a large egg sac attached. The ten hatchlings that we attempted to keep in an aquarium refused to eat and died within a few weeks. The remainder went to Dr. Storey where they were processed for freeze tolerance experiments ${ }^{3}$.

As a Nongame Biologist for over 20 years, I have received dozens of calls from cottage owners (Whiteshell, Turtle Mountains, Spruce Woods, Assiniboine River, etc.) who had found young turtles while raking leaves in the spring. I have also told people who had found turtle nests to cover them with wire mesh as a guard against predation, then to remove the cover the following spring. I did not realize that the spring emergence of young turtles that had hatched the previous fall was in question as being the Manitoba norm.

Most recently, on 9 May, 1998, Walter Smilinsky was digging dandelions in the back yard of his cottage at Brereton Lake in the Whiteshell Provincial Park, $M B$, when he spotted a tiny hatchling painted turtle on the ground some 30 metres from the water's edge. Walter picked it up and put it into Brereton Lake where it swam around and came up for air a number of times before moving out of sight. A day or so later I was talking to C.C. Dixon, a former Wildlife Biologist with the Province of Manitoba, now living near Boissevain Manitoba. He stated that he had just talked to a cot- 


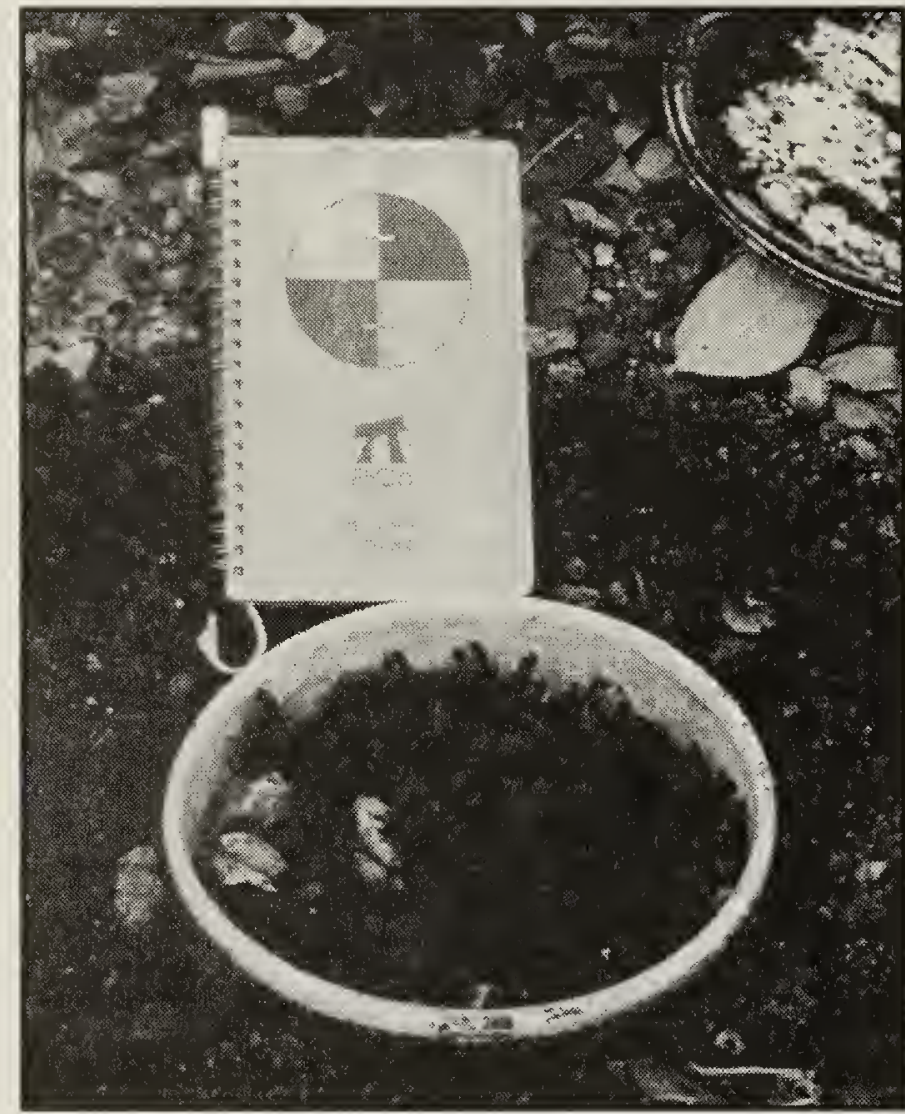

Figure 1

W.H. Koonz

tage owner who had discovered dozens of western painted turtle hatchlings near their cottage on Arbour Island in Max Lake (Turtle Mountain Provincial Park).

After listening to these turtle stories, I contacted Dr. Bill Preston, herpetologist at the Manitoba Museum. Bill informed me that there has been only anecdotal information from Manitoba on the documentation of young painted and snapping turtle nestlings overwintering in their nests. In Dr. Preston's book "The Amphibians and Reptiles of Manitoba"2, he quotes a South Dakota study by Hammer which claims that common snapping turtle hatchlings would die (due to freezing) if they did not emerge from their nests prior to freeze-up in the fall ${ }^{1}$. On the other hand, Yntema suggests that heat may be produced by the developing embryos/hatchlings, thus enabling them to survive the winter ${ }^{5}$. Regarding western painted turtles, Preston quotes Woolverton who studied painted turtle nests and turtle hatchling emerging dates in a northern Minnesota study ${ }^{4}$. He found that many of the hatchlings from one year did not emerge from their nests until as late as
mid-June the following year. Woolverton recorded temperatures in live painted turtle nests as low as $-11^{\circ} \mathrm{C}$. Since many of Manitoba's turtle nests are along the edges of gravel roads, winter nest temperatures could also be well below freezing.

It is hoped that this note will trigger further Canadian prairie turtle nest studies, particularly common snapping turtles, to determine if young turtles emerge in the fall or if they normally overwinter in their nests. If they overwinter in their nests, more work needs to be undertaken to determine how these hatchlings are able to survive the subfreezing temperatures which must occur in their nests.

I wish to acknowledge Dr. Jim Duncan and Dr. R.W. Nero (MB. DNR) for their manuscript ideas and for editing the text.

1. HAMMER, D.A. 1969. Parameters of a marsh snapping turtle population, Lacreek Refuge, Southakota. J. Wildl. Mgmt. 33(4):995-1005.

2. PRESTON, W.B. 1982. The amphibians and reptiles of Manitoba. The Manitoba Museum of Man and Nature. Wpg., MB. ISBN 0-920704-13-1.

3. STOREY, K.B., MCDONALD, D.G., DURMAN, J.G., and STOREY, J.M. 1991. Blood chemistry and ice nucleating activity in hatchling painted turtles. Cryo Lett. 12, 351-358.

4. WOOLVERTON, E. 1963. Winter survival of hatchling painted turtles in northern Minnesota. Copeia, 1963(3):569-570.

5. YNTEMA, C.L. 1978. Incubation times for eggs of the turtle Chelydra serpentina (Testudines; Chelydridae) at various temperatures. Herpetologica, 34(3):274-277. 